\title{
Primary antibody deficiencies in the context of normal B-cell differentiation
}

\author{
$M$ van der Burg \\ From 5th European Workshop on Immune-Mediated Inflammatory Diseases \\ Sitges-Barcelona, Spain. 1-3 December 2010
}

Primary antibody deficiencies (PAD) form the largest group of inherited disorders of the immune system. They are characterized by a marked reduction or absence of serum immunglobulins (Ig) and/or a poor response to vaccination due to disturbed B-cell differentiation. PAD can be divided in agammaglobulinemia, Ig class switch recombination defects (formerly called hyper IgM syndromes), and idiopathic hypogammaglobulinemia, including Common Variable Immunodeficiency Disorders (CVIDs). Although, already 17 genes have been identified to be affected in PAD, for many patients a molecular diagnosis is still not made. A molecular diagnosis is of great importance to both patient and family, because it offers a precise cause and it forms the basis of adequate treatment and estimation of prognosis. Furthermore, understanding the molecular defect supports the development of long-term preventive strategies to limit complications and irreversible organ damage and it contributes to treatment compliance and enables genetic counseling. To understand the consequences of PAD gene defects, it is important to find out which crucial processes are disturbed. All PAD gene defects somehow impaired B-cell differentiation and especially the genes affected in the CVID category are involved in many different processes. During the presentation, the effects of genetic defects will be presented in the context of normal B-cell differentiation. In addition, it will be discussed how new technical developments

Dept. of Immunology, Erasmus MC, University Medical Center Rotterdam, Rotterdam, The Netherlands can support understanding of B-cell differentiation and discovering new genetic defects in PAD.

Published: 25 November 2010

doi:10.1186/1479-5876-8-S1-I11

Cite this article as: van der Burg: Primary antibody deficiencies in the context of normal B-cell differentiation. Journal of Translational Medicine 2010 8(Suppl 1):111.
Submit your next manuscript to BioMed Central and take full advantage of:

- Convenient online submission

- Thorough peer review

- No space constraints or color figure charges

- Immediate publication on acceptance

- Inclusion in PubMed, CAS, Scopus and Google Scholar

- Research which is freely available for redistribution
Ciomed Central 